\title{
Implementasi Media Pembelajaran pada Kecerdasan Bahasa Anak Usia 5-6 Tahun
}

\author{
Reni Ardiana \\ Universitas Widya Gama Mahakan Samarinda \\ e-mail corresponden: reniardiana271283@gmail.com
}

\begin{abstract}
ABSTRAK. Tujuan penelitian ini adalah 1. Memperoleh informasi yang mendalam mengenai cara guru merancang pembelajaran kecerdasan bahasa anak di dalam kelas, 2. Mengetahui pendekatan, metode dan strategi pembelajaran yang dilakukan guru kepada anak dalam mengimplementasikan pembelajaran berbasis kecerdasan bahasa anak, 3. Mengetahui perkembangan kecerdasan bahasa anak setelah pembelajaran berbasis kecerdasan bahasa anak Pengamatan meliputi : Metode pengamatan berperanserta (observasi partisipatif), sebagai tehnik utama untuk mengumpulkan data mengenai pembelajaran kecerdasan bahasa anak, Metode wawancara mendalam yang dilakukan terhadap pengelola, guru dan orang tua murid dalam pengumpulan data yang berhubungan dengan pelaksanaan metode yang diterapkan sebagai proses pembelajaran kecerdasan bahasa anak. Metode dokumentasi sebagai penunjang untuk memperoleh data di lapangan. Tekhnik analisis data yaitu data yang diperoleh dari berbagai sumber baik dari pengamatan, catatan lapangan, dan wawancara. Hasil dari Penelitian adalah sebagai berikut : (1) Guru telah merancang media pembelajaran untuk meningkatkan kecerdasan bahasa anak di dalam kelas. (2) Pelaksanaan pembelajaran menggunakan pendekatan model area dengan menggunakan media belajar seperti kartu huruf, kartu kata, puzzle, serta metode dan strategi bercerita, bercakap-cakap, serta metode membaca yang digunakan dalam pembelajaran kecerdasan bahasa anak. (3) Pembelajaran bahasa anak setelah menggunakan media pembelajaran berbasis kecerdasan bahasa anak di Taman Kanak-kanak Tunas Tridharma Plus Samarinda mengalami perkembangan yang baik yaitu : dapat membaca, bisa menulis sederhana, bercerita, mampu menjawab pertanyaan, menyusun kartu huruf, mampu menyebutkan huruf-huruf abjad dan bisa menulis namanya sendiri. Dan orang tua dapat memahami lebih baik tentang perkembangan bahasa anak dengan cara mengajak anak berkomunikasi / berbicara secara aktif.
\end{abstract}

Kata Kunci : Media belajar; Pembelajaran Kecerdasan Bahasa; Anak Usia 5-6 tahun

ABSTRACT. The purpose of this research is: (1) Get in-depth information about how teachers design children's language intelligence learning in the classroom. (2) Knowing the approaches, methods and learning strategies that teachers do to children in implementing learning based on children's language intelligence., (3) Knowing the development of children's language intelligence after learning children's language intelligence based in kindergarten. Observations include: (1) Participatory observation method (participatory observation), as the main technique for collecting data on children's language intelligence learning. (2) The method of in-depth interviews conducted on managers, teachers and parents of students in collecting data related to the implementation of the 
method applied as a learning process for children's language intelligence in kindergarten. (3) Documentation method as a support to obtain data in the field. Data analysis techniques are data obtained from various sources, both from observations, field notes, and interviews. The results of the study are as follows: (1) The teacher has designed learning media to improve children's language intelligence in the classroom. (2) The implementation of learning uses an area model approach by using learning media such as letter cards, word cards, puzzles, as well as methods and strategies for storytelling, conversing, and reading methods used in learning children's language intelligence. (3) Children's language learning after using learning media based on children's language intelligence experienced good development, namely: being able to read, being able to write simple, telling stories, being able to answer questions, compiling letter cards, being able to name letters. letters of the alphabet and can write his own name. And parents can understand better about children's language development by inviting children to communicate/talk actively.

Keyword : Learning media; Language Intelligence Learning; Children aged 5-6 Years

\section{PENDAHULUAN}

Pada hakikatnya anak adalah manusia kecil yang memiliki potensi yang masih harus dikembangkan. ia memiliki karakteristik yang khas dan tidak sama dengan orang dewasa serta akan berkembang menjadi manusia dewasa seutuhnya. Dalam hal ini anak merupakan seorang manusia atau individu yang memiliki pola perkembangan dan kebutuhan tertentu yang berbeda dengan orang dewasa. Anak memiliki berbagai macam potensi yang harus dikembangkan. Meskipun pada umumnya anak memiliki pola perkembangan yang sama, tetapi ritme perkembangannya akan berbeda satu sama lainnya karena pada dasarnya anak bersifat individual. Pendidikan merupakan usaha yang dilakukan oleh seseorang secara sadar dan terencana untuk mengembangkan potensi peserta didik dan memperlengkapi diri di kemudian hari. Pendidikan dimulai sejak lahir/usia dini sampai ke jenjang pendidikan yang lebih tinggi seperti Perguruan Tinggi. Salah satu yang menjadi program Pemerintah untuk mencerdaskan kehidupan bangsa adalah Pendidikan Anak Usia Dini (PAUD)[1]. Menurut Sujiono pendidikan anak usia dini merupakan pendidikan yang strategis dalam pembentukan manusia yang seutuhnya yang cerdas, berakhlak, berbudi pekerti dan sehat lahir batin dan harus diberikan sebagai bagian bentuk hak asasi anak[2]. Menurut Sumantri anak usia dini berada pada masa lima tahun pertama yang disebut The Golden Age. Masa ini merupakan masa emas perkembangan anak[3].

Salah satu bentuk implementasi media pembelajaran kecerdasan bahasa anak usia 5-6 tahun yakni guru dapat mengembangkan kreativitasnya dalam pembelajaran melalui kegiatan yang telah disusun dalam bentuk rancangan kegiatan pembelajaran. Menurut Arifa bahwa kesiapan sumber daya manusia meliputi pendidik (guru dan dosen), peserta didik, dan dukungan orang tua merupakan bagian terpenting dalam pelaksanaan pembelajaran online[4]. Media pembelajaran dibuat atas dasar untuk 
meningkatkan kecerdasan bahasa anak yang sesuai dengan tahapan perkembangan anak usia dini. Pendidikan yang berlangsung di sekolah selama ini masih menekankan pada pengembangan kecerdasan intelektual yang mementingkan kemampuan logika matematika dan bahasa. Agar pertumbuhan dan perkembangan tercapai secara optimal, maka dibutuhkan situasi yang kondusif pada saat memberikan stimulasi yang sesuai dengan kebutuhan dan minat anak. Anak berkembang dari berbagai aspek yaitu berkembang fisiknya, baik motorik kasar maupun halus, berkembang aspek kognitif, aspek sosial dan emosional. Belajar adalah suatu proses yang kompleks yang terjadi pada diri setiap orang sepanjang hidupnya. Proses belajar terjadi karena adanya interaksi antara seseorang dengan lingkungannya. Belajar dapat terjadi kapan saja dan di mana saja. Belajar ditandai oleh adanya perubahan tingkah laku pada diri seseorang. Perubahan itu bisa mencakup pengetahuan, keterampilan, atau sikapnya[5]. Menurut Kemp, Dkk yang dikutip dari Rohmani menyatakan jika gangguan berbahasa dan berkomunikasi dapat menghambat dalam memahami dan memproduksi bahasa. Kedua hal ini termasuk keluaran dari proses pengolahan informasi, pesan dan pikiran yang diikuti pemilihan kata yang tepat sehingga penjelasan secara verbal dapat dipahami lawan bicara[6].

Proses belajar yang diselenggarakan di sekolah adalah untuk mengarahkan perubahan yang ada pada diri anak. Interaksi yang terjadi selama kegiatan dalam pembelajaran Interaksi yang terjadi selama proses belajar mengajar tersebut dipengaruhi oleh lingkungannya, antara lain murid, guru, kepala sekolah, media pembelajaran, bahan atau materi pembelajaran, berbagai sumber belajar, dan lain-lain. Dengan media pembelajaran proses belajar-mengajar diharapkan berlangsung secara efektif dan efisien. Menurut Suyadi bahwa Anak usia dini mengalami pertumbuhan dan perkembangan yang sangat pesat sehingga membutuhkan stimulasi yang sesuai dengan kebutuhan anak-anak. Stimulasi tersebut salah satunya dapat diperoleh dari PAUD. PAUD merupakan upaya pembinaan dan melalui pemberian rangsangan pendidikan untuk membantu pertumbuhan dan perkembangan jasmani dan rohani agar anak dapat memiliki kesiapan dalam memasuki pendidikan lebih lanjut[7].

Berdasarkan uraian yang telah dipaparkan dalam latar belakang tersebut, maka dalam penelitian ini, peneliti memfokuskan pada TK Tunas Tridharma Plus Samarinda sebagai area penelitian dala judul Implementasi Media pembelajaran kecerdasan bahasa anak usia 5-6 tahun. Ada banyak definisi kecerdasan, kecerdasan dapat dilihat dari berbagai pendekatan, yakni pendekatan teori belajar, teori neurobiologist, teori psikometri dan pendekatan teori perkembangan. Kecerdasan dapat diperkirakan dan diklasifikasikan berdasarkan tes inteligensi. tokoh pengukuran inteligensi Alfred Binet mengatakan bahwa kecerdasan adalah kemampuan yang terdiri dari tiga komponen,yakni (1) kemampuan untuk mengarahkan pikiran , (2) kemampuan untuk mengubah arah pikiran atau tindakan, dan (3) kemampuan untuk mengkritisi pikiran dan tindakan diri sendiri.

Tujuan belajar melalui bermain pada anak usia dini adalah diarahkan untuk mengembangkan berbagai potensi anak sejak dini sebagai persiapan untuk hidup dan 
dapat menyesuaikan diri dengan lingkungannya, termasuk siap mengikuti pendidikan di sekolah dasar. Tujuan belajar dikembangkan berdasarkan kompetensi dasar , antara lain di dalam PERMENDIKBUD N0.146 Tahun 2014 terdapat 6 bidang pengembangan, yaitu pengembangan agama dan moral, fisik motorik, , kognitif, bahasa, sosial emosional dan seni. Subjek yang diteliti dalam penelitian ini adalah guru, dimana masalah yang ada adalah media belajar yang digunakan mampu mengembangkan kecerdasan bahasa anak usia dini. Bahasa adalah sebagai salah satu fumgsi komunikasi dan juga merupakan saran yang penting dalam kehidupan anak. Melaluli bahsa, anak dapat saling berhubungan, saling berbagi pengalaman dan juga dapat meningkatkan intelektual anak. Orang tua dan guru sebagai orang yang bertanggung jawab terhadap perkembangan bahasa anak[8].

Para ahli berbeda pendapat tentang faktor-faktor yang mempengaruhi kemampuan bahasa individu. Beberapa ahli meyakini bahwa bahasa merupakan kemampuan yang di peroleh sejak lahir, sedangkan para ahli yang lain mempercayai pengaruh faktor eksternal terhadap kemampuan bahasa maupun interaksi antara kedua faktor tersebut. Terdapat hubungan yang signifikan antara pola asuh orang tua terhadap perkembangan bahasa anak usia prasekolah di PAUD Al-Hasanah Pekanbaru Tahun 2012. Dengan demikian dapat disimpulkan perkembangan bahasa anak sangat dipengaruhi pola asuh orang tua [9]. Saran Menurut teori Nativis meyakini bahwa kemampuan bahasa dipengaruhi oleh kematangan seiring dengan pertumbuhan anak. Pandangan para ahli Nativis yang memisahkan antara belajar bahasa dengan perkembangan kognitif di kritik berkenaan dengan kenyataan bahwa anak belajar bahasa dari lingkungan sekitarnya dan memiliki kemampuan untuk mengubah bahasanya jika lingkungannya.

\section{METODE}

Kegiatan penelitian ini menggunakan metode observasi dengan Subjek penelitiannya adalah 3 orang guru di TK Tunas Tridrama Plus Samarinda, Penelitian ini menggunakan pendekatan penelitian kualitatif. Metode kualitatif ini digunakan karena beberapa pertimbangan. Pertama, menyesuaikan metode kualitatif lebih mudah apabila berhadapan dengan kenyataan ganda; kedua, metode ini menyajikan secara langsung hakikat hubungan antara peneliti dengan koresponden; dan ketiga, metode ini lebih peka dan lebih dapat menyesuaikan diri dengan banyak penajaman pengaruh bersama dan terhadap pola-pola nilai yang dihadapi. Penelitian kualitatif pada dasarnya adalah pengumpulan data dari objek yang empiris melalui studi kasus, pengalaman personal, pendekatan natural, introspektif, kisah nyata, interview, observasi, pendekatan historis, intraksional, penelusuran melalui teks visual yang masing-masing menjelaskan permasalahan dari sebuah kehidupan individu, kelompok, komunitas, maupun organisasi, misalnya sejarah, biografi, gender, kelas sosial, etnis, dan sebagainya. Adapun penyusunan desain atau rancangan penelitian diarahkan oleh komponen-komponen penelitian yang telah dirumuskan terlebih dahulu.

Berdasarkan jenis penelitian yang bersifat kualitatif, maka analisa data berlangsung selama dan setelah pengumpulan data. Proses analisis mengalir dari tahap 
awal hingga tahap penarikan kesimpulan hasil studi. Agar data yang diperoleh lebih bermakna, teknik analisis data dilakukan melalui empat komponen yang saling berhubungan yaitu :

1. Pengumpulan data, yang dilakukan dengan menggunakan observasi dengan wawancara.

2. Reduksi data, yaitu diartikan sebagai pemusatan penyederhanaan, pengabstrakkan, transformasi data kasar dari catatan lapangan. Dengan demikian data yang telah direduksi akan memberikan gambaran yang jelas, dan mempermudah peneliti untuk melakukan pengumpulan data selanjutnya dan mencari bila diperlukan, maka akan memudahkan untuk memahami apa yang terjadi, merencanakan kerja selanjutnya berdasarkan apa yang dipahami. Penyajian data, berupa teks naratif dari catatan lapangan yang telah digolongkan sesuai dengan topik masalah.

Data yang dikumpulkan melalui penelitian ini adalah data yang sesuai dengan fokus penelitian, yaitu tentang (1) rancangan pembelajaran yang berupa silabus dan rencana pelaksanaan pembelajaran, (2) pelaksanaan pembelajaran dengan acuan kegiatan yang dilakukan pendidik pada saat proses belajar mengajar baik pada awal, inti, ataupun kegiatan akhir, dan (3) evaluasi pembelajaran dengan fokus data laporan perkembangan anak.

\section{HASIL DAN PEMBAHASAN}

Berdasarkan seluruh catatan dilapangan, Tim pelaksana kegiatan membuat surat izin untuk melakukan kegiatan observasi penelitian kepada kepala TK. Setelah itu melakukan observasi belajar anak pada kegiatan awal ,kegiatan inti,dan kegiatan akhir belajar anak. Dalam kegiatan pembelajaran dengan media sangatlah baik untuk menunjang belajar anak di sekolah,penggunaan media yang dibuat oleh guru walaupun sederhana tetapi anak-anak sangat menyukainya, dan dari media sederhana tersebut juga dapat mengembangkan kecerdasan bahasa anak,seperti mengenalkan huruf, membaca, mengenalkan bentuknya serta bunyi. Pola pikir yang positif dapat membantu menerapkan media pembelajaran daring, sehingga menghasilkan capaian pembelajaran yang tetap berkualitas. Belajar di rumah dengan menggunakan media daring mengharapkan orangtua sebagai role model dalam pendampingan belajar anak, dihadapi perubahan sikap[10]. Menurut Munandar, dalam mengajar penting bagi pendidik untuk dapat membuat siswa terangsang dan tertarik untuk belajar. Untuk anak usia dini mengenalkan matematika berupa konsep geometri, konsep mengenal warna, pengenalan angka permulaan, namun sebagian besar dari anak beranggapan bahwa hal tersebut merupakan materi yang lebih rumit untuk mereka selesaikan, terutama pada mengenal bentuk geometri[11]. Kegiatan selanjutnya mengevaluasi hasil observasi penelitian untuk mengetahui apakah implementasi media pembelajaran kecerdasan anak selama penelitian ada peningkatan dalam kualitas belajar anak di kelas. Implementasi menurut bahasa adalah pelaksanaan atau penerapan. Implementasi merupakan suatu proses penerapan ide, kebijakan, atau inovasi dalam suatu tindakan praktis sehingga memberikan dampak, baik berupa perubahan pengetahuan, keterampilan maupun nilai, dan sikap [12].

Upaya guru dalam menciptakan suatu sistem lingkungan yang memungkinkan terjadinya proses pembelajaran merupakan suatu keharusan, dengan maksud agar 
tujuan pembelajaran dapat dicapai secara optimal, oleh karena itu guru dituntut untuk menyusun rencana pelaksanaan pembelajaran harian. Gagne menyatakan bahwa media adalah berbagai jenis komponen dalam lingkungan siswa yang dapat merangsangnya untuk belajar[13]. Dalam kegiatan ini Peneliti mengobservasi setiap kegiatan yang dilakukan oleh guru dalam implementasi media pembelajaran anak untuk mengembangkan kecerdasan bahasa. Peneliti melihat rancangan kegiatan pembelajaran guru dikelas, serta Peneliti melakukan wawancara kepada guru sebagai subjek utama penelitian, sedangkan orang tua dan kepala sekolah sebagai informan yang dilakukan oleh peneliti untuk mendapatkan keabsahan data penelitian tentang kegiatan pelaksanaan pembelajaran anak dengan menggunakan media pembelajaran untuk mengembangan kecerdasan bahasa anak dan yang tidak menggunakan media pembelajaran. Pada saat kegiatan tersebut peneliti mengobservasi apakah implementasi media pembelajaran pada kecerdasan bahasa anak usia 5-6 tahun di TK Tunas Tridharma Plus sudah dilakukan sehingga terjadi peningkatan dalam kecerdasan bahasa anak dengan menggunakan media pembelajaran.

Penelitian relevan dengan penelitian ini adalah pertama Evi Tobeli dengan judul penelitian" model pembelajaran berbasiskan kecerdasan majemuk dan penerapannya dalam proses pembelajaran anak usia dini", tujuan penelitian ini mempersiapkan siswa untuk berhasil dalam melanjutkannya dan pengalaman pendidikan dan mengembangkan potensinya secara maksimal.Penelitian ini memiliki kemiripan dengan yang dilakukan penulis yaitu sama-sama menjelaskan tentang kecerdasan tetapi fokus nya berbeda, yaitu jurnal evi tobeli tentang model pembelajaranberbasis kecerdasan majemuk serta penerapannya[1]. Kedua oleh Khoerotul dengan judul penelitian "Optimalisasi kecerdasan verbal linguistic anak usia dini dalam pembelajaran melalui audio visual, tujuan nya adalah muntuk mengetahui bagaimanakah optimalisasi kecerdasan verbal linguistic anak usia dini dalam pembelajaran melalui audio-visual. Penelitian tesebut memiliki kemiripan dengan penelitian yang dilakukan penulis yaitu sama-sama melakukan penelitian kecerdasan Bahasa anak atau verbal linguistik anak, namun berbeda fokus penelitiannya yaitu Implementasi media pembelajaran pada kecerdasan bahasa anak usia 5-6 tahun[14]. Penelitian Eneng Hemah dengan judul"meningkatkan kemampuan bahasa anak melalui metode bercerita " ini memiliki kesamaan dengan penelitian dari penulis yaitu sama-sama meneliti tentang kecerdasan anak usia 5-6 tahun akan tetapi yang berbedasa adalah fokus dari penelitiannya dan metode penelitianya.[15]

Dalam hal ini peneliti melihat proses pembelajaran dari observasi awal yaitu apayang dilakukan oleh guru di sekolah sudah baik, Dalam mengembangkan kreativitas guru untuk media pembelajaran dilakukan dengan baik guru membuat media seperti kotak pintar, mobil pintar, kartu huruf menggunakan bahan bekas dapat menunjukkan kemampuan guru dalam mempersiapkan pembelajaran dikelas. Guru juga melakukan strategi- strategi yang baik dalam proses pembelajaran anak untuk meningkatkan kecerdasan bahasa sesuai anak sesuai dengan perkembangannya. Semua yang dilakukan guru juga mendapatkan dukungan dari kepala sekolah. Setiap pendidik harus bisa meningkatkan kreativitas dalam setiap pebelajaran, baik dengan menggunakan media pembelajaran yang sesuai dengan aspek perkembangan anak[16]. 


\section{KESIMPULAN}

Berdasarkan pembahasan di atas maka dapat disimpulkan bahwa dalam setiap pembelajaran hendaknya guru bisa menambah kreatifitasnya dalam membuat media belajar anak yang menarik, untuk mampu mengembangkan kecerdasan bahasa anak sesuai dengan aspek perkembangannya. Melalui media pembelajaran atau APE yang digunakan untuk anak- anak seperti membuat mobil pintar, kotak pintar, kartu huruf dan lain-lain yang dapt mengembangakan kecerdasan bahasa anak usia dini sehingga mereka dapat mengikuti kegiatan belajar yang sangat menyenangkan atau tidak membosankan bagi anak. Dalam proses pembelajaran di TK Tunas Tridharma Plus, aspek-aspek yang diharapkan dapat dicapai dalam bidang pengembangan pembiasaan dan dalam bidang kemampuan dasar. Adapun dilakukan guru sebelum melaksanakan yaitu: 1. Guru membuat rencana pelaksanaan pembelajaran 2. Guru mempelajari buku petunjuk penggunaan media 3. Guru menyiapkan dan mengatur peralatan media yang akan digunakan 4. Guru memastikan media dan semua peralatan telah lengkap dan siap digunakan 5. Guru menjelaskan tujuan yang akan dicapai 6. Guru menjelaskan materi kepada anak 7. Guru melakukan evaluasi setelah melaksanakan kegiatan.

\section{PENGHARGAAN}

Terima kasih penulis ucapkan kepada Kepala Sekolah dan Guru di Tk Tunas Tridrama Plus Samarinda yang terlibat dan membantu terlaksananya penelitian ini. Tidak lupa diucapan terima kasih kepada editor dan reviewer Jurnal Murhum yang sudah memberikan kesempatan sehingga jurnal bisa untuk dipublish/diterbitkan.

\section{REFERENSI}

[1] E. Tobeli, "Model Pembelajaran Berbasis Kecerdasan Majemuk dan Penerapannya dalam Proses Pembelajaran Anak Usia Dini," 2009.

[2] K. Maryani, "Penilaian dan Pelaporan Perkembangan Anak Saat Pembelajaran di Rumah di Masa Pendemi Covid-19," Murhum J. Pendidik. Anak Usia Dini, vol. 1, no. 1, pp. 41-52, 2020, doi: 10.37985/murhum.v1i1.4.

[3] S. Suriati, S. Kuraedah, E. Erdiyanti, and L. O. Anhusadar, "Meningkatkan Keterampilan Motorik Halus Anak melalui Mencetak dengan Pelepah Pisang," J. Obs. J. Pendidik. Anak Usia Dini, vol. 4, no. 1, p. 211, Nov. 2019, doi: 10.31004/obsesi.v4i1.299.

[4] M. Shaleh and L. Anhusadar, "Kesiapan Lembaga PAUD dalam Pembelajaran Tatap Muka pada New Normal," J. Obs. J. Pendidik. Anak Usia Dini, vol. 5, no. 2, pp. 2158-2167, Mar. 2021, doi: 10.31004/obsesi.v5i2.1139.

[5] Prihadi, “Media Pembelajaran Bahasa Indonesia," Direktorat Jendral Pendidikan Lanjutan Pertama Kemendinas. pp. 1-43, 2010.

[6] L. Fertiliana Dea, A. Setiawan, and L. Asmiyati, "Upaya Meningkatkan Kemampuan Bahasa Anak Usia 4-5 Tahun Melalui Metode Bernyanyi Menggunakan Media Kartu Gambar," Murhum J. Pendidik. Anak Usia Dini, vol. 1, no. 1, pp. 53-64, Jul. 2020, doi: 10.37985/murhum.v1i1.6.

[7] L. Anhusadar, "Evaluasi Pelaksanaan Standar Produk Hasil Belajar pada Satuan Pendidikan Anak Usia Dini," Al-TA'DIB J. Kaji. Ilmu Kependidikan, vol. 13, no. 1, p. 34, Jun. 2020, doi: 10.31332/atdbwv13i1.1775.

[8] E. Zubaidah, Draft buku pengembangan bahasa. 2003. 
[9] Joni, "Hubungan pola asuh orang tua terhadap perkembangan bahasa anak prasekolah," J. paud tambusai, vol. 1, no. 6, pp. 42-48, 2015, doi: https://doi.org/10.31004/obsesi.v1i1.54.

[10] L. G. M. Z. Atsani, "Transformasi media pembelajaran pada masa Pandemi COVID19," Al-Hikmah J. Stud. Islam, vol. 1, no. 2, pp. 44-54, 2020, [Online]. Available: http://ejournal.kopertais4.or.id/sasambo/index.php/alhikmah/article/view/38 68.

[11] F. D. T. Santana, R. Purwasih, and ..., "Pelatihan Media Interaktif Berbasis Geogebra Bagi Guru Tk Di Era Covid-19," in Prosiding Seminar Nasional Rekarta 2020, 2020, pp. 6-7, [Online]. Available: http://journal-litbangrekarta.co.id/index.php/semarta/article/view/298.

[12] L. R. Pratama and D. E. Priyantoro, "Mengembangkan Membaca Dan Menulis Permulaan Anak Usia Dini," Semin. Nas. Pembelajaran Baca Tulis Hitung Tingkat Permulaan Bagi AUD, pp. 61-74, 2017.

[13] O. N. Mahnun, "Media Pembelajaran (Kajian terhadap Langkah-langkah Pemilihan Media dan Implementasinya dalam Pembelajaran )," An-Nida', vol. 37, no. 1, pp. 27-33, 2012, doi: 10.24014/an-nida.v37i1.310.

[14] K. Mahmudah, "Optimalisasi Kecerdasan Verbal Linguistik Anak Usia Dini Dalam Pembelajaran Melalui Media Audio Visual Di Tk Islam Ta'allumul Huda Bumiayu Tahun," J. Chem. Inf. Model., vol. 53, no. 9, pp. 1689-1699, 2018.

[15] E. Hemah, T. Sayekti, and C. Atikah, "Meningkatkan Kemampuan Bahasa Anak Melalui Metode Bercerita Pada Anak Usia 5-6 Tahun," J. Penelit. dan Pengemb. Pendidik. Anak Usia Dini, vol. 5, no. 1, p. 1, May 2018, doi: 10.30870/jpppaud.v5i1.4675.

[16] R. Nuraini, "Upaya Meningkatkan Kecerdasan Kinestetik Melalui Kegiatan Menari Lagu Tokecang," CERIA (Cerdas Energik Responsif Inov. Adapt., vol. 1, no. 1, p. 31, Jan. 2018, doi: 10.22460/ceria.v1i1.p31-49. 